\section{The influence of project leaders' behavioral competencies on the performance of Six Sigma projects}

\author{
Daniela Santana Lambert Marzagáo \\ Marly M. Carvalho \\ University of São Paulo, Production \\ Engineering DepartmentSão Paulo, Brazil
}

Received on

04/11/2015

Approved on

05/25/2016

Responsible editor:

Prof. Dr. João Maurício Gama

Boaventura

Evaluation process:

Double Blind Review

\begin{abstract}
Purpose - This article aims to characterize behavioral competencies of Six Sigma Project Leaders, as well as relate those competencies with projects performance.

Design/methodology/approach - It is a survey-based research. This study analyzes 225 Six Sigma Projects in Brazil, Chile and Colombia, led by 191 Project Leaders.

Findings - The projects were classified accordingly with their performance and project leaders had their behavioral characteristics mapped. Based on independence statistical testing, it was identified that project success depends on both competencies of the project leader, innovation and direction.
\end{abstract}

Originality/value - The article shows the relationship between behavioral competencies and project performance. In addition, the article maps behavioral competencies in six sigma projects.

Keywords - Project leader; project manager; project success; Six Sigma.

\title{
9
}




\section{Introduction}

Many authors mention that, for the successful implementation of Six Sigma projects, companies must carefully select project leaders in order to ensure their competence in project management (Gijo \& Rao, 2005; Johnson \& Swisher, 2003). According to Boyatzis (1982), competence is a widely used term that can have many meanings, but it generally encompasses issues such as knowledge, competencies, attitudes and behavior referring to superior performance.

In the context of project management, the topic of the individual competencies of project managers has also received special attention from both professional and academic communities. Project management associations such as the International Project Management Association and the Project Management Institute have established responsibility frameworks for project managers. Stevenson \& Starkweather (2010) point to the rise of professional certifications within project management. On the other hand, research indicates the impact of project managers' competencies on the success of projects (Chipulu, Ojiako \& Williams, 2013), although little attention has been given to project managers' career models (Bredin \& Soderlund, 2013).

Ahsan, Ho \& Khan (2013) researched the desired profile in job vacancies for project managers and perceived emphasis on soft skills, involving behavioral aspects (Carvalho, 2014; Clarke, 2010a; Dainty, Cheng \& Moore, 2005; Muller \& Turner, 2010; Skulmoski \& Hartman, 2010; Stevenson \& Starkweather, 2010).

Although it is a relevant topic, there is a lack of research concerning Six Sigma projects. Given this gap, the purpose of this article is to identify key Six Sigma project leaders' competencies and relate them to project performance. To achieve this goal, the researchers gathered data from 191 project leaders in charge of 225 Six Sigma projects performed in companies from the industrial and services sectors in Brazil,
Chile, and Colombia. The Predictive Index $\left(\mathrm{PI}^{\oplus}\right)$ was applied for measuring project leaders' behavior; this is a self-assessment tool based on the behaviorist theory, which allows you to measure and report the professional behavior comparing to the adult population (Harry, Mann, Hodgins, Hulbert \& Lacke, 2010).

This article contains five sections. Section 2 presents the synthesis of the theoretical framework, exploring the main aspects related to Six Sigma and project managers' competencies. Section 3 presents the detailed methodological approach used in the research. Section 4 presents the study results, and Section 5 the discussion of the main findings. Conclusions are presented in Section 6.

\section{Literature review}

According to the literature review carried out by Kwak \& Anbari (2006) in the context of project management over the past 50 years, there are a number of new and relevant topics to this knowledge area, including the Six Sigma as one of the topics that deserve to be studied in depth from the project management perspective.

Six Sigma arose at Motorola and spread especially among large companies (Harry \& Schroeder, 2000; Pande, Neuman \& Cabanagh, 2001). Although Kaynak (2003) considers Six Sigma as a "TQM with steroids", Schroeder, Linderman, Liedtke \& Choo (2008) and Zu, Fredendall \& Douglas (2008) indicate that Six Sigma uses a common platform of knowledge, practice, and quality resources, complementing them with certain features and specific resources in order to increase effectiveness.

To Linderman, Schroeder, Zaheer \& Choo (2003, p. 195) "Six Sigma is an organized and systematic method for strategic process improvement and new product and service development that relies on statistical methods and the scientific method to make dramatic reductions in customer defined defect rates."

To Schroeder et al. (2008, p. 540) Six Sigma has "four relevant constructs or 
elements (parallel-meso structure, improvement specialists, structured method, and performance metrics)." This parallel-meso structure provides a hierarchical structure independent of the organizational structure, where continuous improvement experts, called "belts", lead the projects, supported by companies' executives, the so-called "champions." Six Sigma dedicates itself to improving the organization and organizational change management. To Choo, Linderman \& Schroeder (2007), Six Sigma has a positive impact on learning and knowledge management.

An important feature of Six Sigma that refers to the field of project management is its projectized structure. Zu et al. (2008) have shown that the core activities that differentiate Six Sigma from other quality initiatives are its structured procedures for improvement, characterized by disciplined and standardized execution of planned improvement activities through projects. Linderman et al. (2003) highlight the projectbased characteristic of Six Sigma and its specific goals to offer a differentiated performance facing other improvement initiatives. Snee (2001, p. 66) proposes a definition of Six Sigma projects as "aimed at the problem in which the solution is not known...we also need one or more measurements that quantify the magnitude of the problem and can be used to select the project goals and monitor progress."

Six Sigma has a program structure, deployed in projects carried out following the same management and methodology. According to the Project Management Body of Knowledge (PMBOK) definition, (PMI, 2008), a program can be defined as a group of related projects managed in a coordinated manner to achieve strategic benefits and control that would not be available if they were individually managed.

Thus, it is possible to deploy Six Sigma within enterprises as a Program organized through projects in order to improve processes, increase customer satisfaction and financial results.

\section{I The role of Six Sigma project leaders}

The program structure offers levels of proficiency of experts on Six Sigma methods, tools and techniques, and in dedication to the program specialist. The hierarchy of this structure is similar to martial arts, thus the term "belts." Leaders of Six Sigma projects are in general Black Belts, while Green Belts tend to support, but can also eventually lead projects.

According to Schroeder et al. (2008), the Black Belt is a full-time, well-trained specialist, who serves as a highly qualified project leader and reports to high leadership. The Black Belts' selection is not only based on technical competencies, but also on leadership competencies. Green Belts receive fewer hours of training in Six Sigma and, in general, work part-time on projects, while Black Belts receive extensive training and are responsible for providing assistance to Six Sigma project teams, supporting as mentors and supporting training activities.

Davison \& Al-Shaghana (2007) identified differences between companies that have and don't have Six Sigma regarding human resources, such as training, employees' participation and creating quality awareness. Buch \& Tolentino (2006) also mention that the employees believe that their participation in the Six Sigma program will add value to their carrier and the organization. Kumar \& Antony (2008) also identified differences between knowledge transfer among SMEs (small and medium-sized enterprises) which adopt Six Sigma and ISO (International Organization for Standardization) in the United Kingdom.

Since Six Sigma program can be analyzed according to the perspective of programs, Table 1 compares critical success factors (FCS) for projects as discussed by Shao \& Muller (2011) with critical success factors mentioned in Six Sigma literature. 
Table 1

Comparison between FCS (Shao, \& Muller, 2011) and Six Sigma literature FCS

\begin{tabular}{|c|c|}
\hline $\begin{array}{c}\text { Critical Success Factors for Programs (Shao e } \\
\text { Muller, 2011) }\end{array}$ & Six Sigma literature support \\
\hline Stability of the program context & $\begin{array}{l}\text { Cooke-Davies (2002); Kessler \& Winkelhover (2002); Pinto \& Prescott } \\
\text { (1988); Rabechini et al. (2002); The Standish Group (2009); Van Iwaarden } \\
\text { et al. (2008) }\end{array}$ \\
\hline Support for the program context & $\begin{array}{l}\text { Belout \& Gauvreau (2004); Carvalho et al. (2007); Davison \& Al-Shaghana } \\
\text { (2007); Kessler \& Winkelhover (2002); Kondic et al. (2009); Kumar e } \\
\text { Antony (2008); Trad \& Maximiniano (2009) }\end{array}$ \\
\hline Hamony within the programa & $\begin{array}{l}\text { Chang Dong \& Zai (2004); Kessler \& Winkelhover (2002); White \& Fortune } \\
\text { (2002) }\end{array}$ \\
\hline Interaction between the program and its context & $\begin{array}{l}\text { Kumar \& Antony (2008); Rabechini, Carvalho \& Laurindo (2002); Van } \\
\text { Iwaarden et al. (2008); White \& Fortune (2002) }\end{array}$ \\
\hline intellectual competencies of the program leader & $\begin{array}{l}\text { Archibald (2003); Chang Dong \& Zai (2004); Kumar \& Antony (2008); } \\
\text { Rabechini, Carvalho \& Laurindo (2002) }\end{array}$ \\
\hline Managerial competencies of program leader & $\begin{array}{l}\text { Archibald (2003); Chang Dong \& Zai (2004); Kumar \& Antony (2008); } \\
\text { Rabechini, Carvalho \& Laurindo (2002) }\end{array}$ \\
\hline Program type & Larson \& Gobeli (1989); Shenhar \& Dvir (2007) \\
\hline Program scope & Belout \& Gauvreau (2004) \\
\hline
\end{tabular}

Since project leaders' competencies are one of the key critical success factors, we decided to explore their impact on the success of Six Sigma projects.

Gijo \& Rau (2005) identify the obstacles to the implementation of Six Sigma, highlighting the difficulty in project execution due to a lack of resources and the difficulty in selecting people with interpersonal competencies to lead projects. Several authors show the importance of careful selection of project leaders based on their leadership competencies (Johnson \& Swisher, 2003; Zu, Fredendall \& Douglas, 2008). However, Six Sigma project leaders' key competencies have not been properly described. The literature of the Project Management field has devoted more attention to the behavioral competencies required of project managers.

\subsection{Project managers' competencies}

Some of the major associations and institutes dedicated to the field of project management have individual competencies of project managers' guidelines. Among the most widespread is the Competence Baseline of International Project Management Association
(IPMA, 2006) and the Project Manager Competency Development Framework (PMCDF) from the Project Management Institute (PMI, 2007). A comparative analysis of these reference models shows that there are similarities between them with regard to behavioral competencies.

The Project Manager Competency Development Framework (PMCDF) (PMI, 2007) describes knowledge, performance and personal competencies. Knowledge competencies are described in the PMBOK, currently in its $5^{\text {th }}$ edition (PMI, 2013); performance and personal competencies, on the other hand, are formed by units of competence, for example, "project planning," deployed in elements of competence (approved project schedule, etc.). Similarly, the ICB presents technical competencies (in Project Management and behavioral), but also highlights contextual competencies (IPMA, 2006).

There is less consensus within academic literature. To Caupin et al. (1999), a project manager should be someone with communication competencies, initiative and motivation, openminded, responsive, sensitive, unbiased, conflict solver, problem solver and leadership. Brill, Bishop \& Walker (2006) present a list with 
117 in nine groups of competencies: problem solving, leadership, knowledge of the context, analytical competencies, ability to handle people, communication, personal characteristics, project administration, and tools. Rose, Pedersen, Hosbond \& Kraemmergaard (2007) identified seven competencies: process, time, customer, business, personal and technical uncertainty management. To Crawford (1998), a project leader must be action-oriented and resultoriented, and personal competencies and personal effectiveness.

The leader or project manager has the role of coordinating the teamwork in search of a better result, which requires not only technical knowledge of the leader on the project subject but also behavioral competencies that will facilitate the project execution. Project management literature evolves towards the competencies needed for a project leadership.

According to Shtub \& Globerson (1994), the competencies required of the project manager refers to leadership, negotiation, and technical competencies. While the technical competencies can vary according to project scope, the behavioral competencies are similar across the projects, as summarized in Table 2.

\section{Table 2}

\section{Evolution of literature on the behavioral competencies of project managers}

\begin{tabular}{|c|c|c|c|c|c|c|}
\hline $\begin{array}{l}\text { Ménard } \\
(1981)\end{array}$ & $\begin{array}{l}\text { Adams et al. } \\
\text { (1979) }\end{array}$ & $\begin{array}{c}\text { Roberts } \\
\text { \&Fusfeld (1981) }\end{array}$ & $\begin{array}{l}\text { Martin } \\
(1978)\end{array}$ & $\begin{array}{l}\text { Shanks } \\
(1983)\end{array}$ & $\begin{array}{l}\text { Wilemon \& } \\
\text { Cicero (1970) }\end{array}$ & Spitz (1982) \\
\hline & & Designer & & $\begin{array}{l}\text { Results } \\
\text { Manager }\end{array}$ & & \\
\hline & & Problem solver & & $\begin{array}{c}\text { Work } \\
\text { Manager }\end{array}$ & & Planner \\
\hline & & Entrepreneur & & & & \\
\hline \multirow[t]{2}{*}{ Strategist } & Communicator & $\begin{array}{l}\text { Extended } \\
\text { information }\end{array}$ & $\begin{array}{l}\text { Relations } \\
\text { with the High } \\
\text { Representative } \\
\text { leadership }\end{array}$ & & & $\begin{array}{l}\text { Extended } \\
\text { information }\end{array}$ \\
\hline & & & & $\begin{array}{l}\text { Resource } \\
\text { Manager }\end{array}$ & $\begin{array}{l}\text { Organizational } \\
\text { constraints }\end{array}$ & Communicator \\
\hline \multirow[t]{2}{*}{ Pilot } & Decision maker & Driver & Decision maker & & Risks & $\begin{array}{c}\text { Identifies and } \\
\text { acquires resources }\end{array}$ \\
\hline & & & & $\begin{array}{l}\text { Risk and } \\
\text { crisis } \\
\text { manager }\end{array}$ & $\begin{array}{c}\text { Balance between } \\
\text { x management } \\
\text { technician }\end{array}$ & \\
\hline \multirow[t]{3}{*}{ Coordinator } & Integrator & & Integrator & & & Coordinator \\
\hline & Team leader & Sponsor & & & $\begin{array}{l}\text { Interpersonal } \\
\text { relations }\end{array}$ & Controller \\
\hline & $\begin{array}{l}\text { Responsible } \\
\text { climate }\end{array}$ & & & & & Catalyst \\
\hline
\end{tabular}

Note. Source: Adapted from "Examining effective technology project leadership traits and behaviours", de K. D. Strang, 2007, Computers in Human Behaviour, 23, 424-462. 
Another way to organize the roles of project leader is to separate the technical and managerial roles, according to the Mintzberg
(1975), the transactional leader roles and continuous processing of Bass (1985). An example of this application can be seen in Table 3 .

\section{Table 3}

\section{Separation of technical and managerial roles of project leaders}

\begin{tabular}{|c|c|c|}
\hline Technical and managerial leadership & Values & Transformational behaviors \\
\hline $\begin{array}{l}\text { Innovative (creative solution to problems, } \\
\text { adaptation) }\end{array}$ & \multirow[t]{2}{*}{$\begin{array}{l}\text { Open mind, Adaptive } \\
\text { Leadership }\end{array}$} & \multirow[t]{2}{*}{ Motivation for inspiration, intellectual stimulation } \\
\hline Broker (power, influence, resource acquisition) & & \\
\hline $\begin{array}{l}\text { Facilitator (conflict management, participatory } \\
\text { decision making) }\end{array}$ & \multirow[t]{2}{*}{$\begin{array}{l}\text { Human relations } \\
\text { Leadership of people }\end{array}$} & \multirow{2}{*}{$\begin{array}{l}\text { Individualized consideration, } \\
\text { Support from other } \\
\text { Negotiator behavior }\end{array}$} \\
\hline Mentor (development) & & \\
\hline Coordinator (coordination of tasks, budget control) & \multirow{2}{*}{$\begin{array}{l}\text { Creating routines } \\
\text { Stability of leadership }\end{array}$} & \multirow{4}{*}{$\begin{array}{l}\text { Focus on the performance of tasks to achieve } \\
\text { organizational goals }\end{array}$} \\
\hline $\begin{array}{l}\text { Monitor (information management, critical } \\
\text { thinking) }\end{array}$ & & \\
\hline Producer (productivity, efficiency) & \multirow{2}{*}{$\begin{array}{l}\text { Rational goals, } \\
\text { Task leadership }\end{array}$} & \\
\hline Director (Planner, goals) & & \\
\hline
\end{tabular}

Note. Source Strang (2007). Examining effective technology project leadership traits and behaviors. Computers In Human Behaviour, 23(1), 424-462

According to Somerville \& Langford (1994), the sources of stress and conflict in projects may be related to recognition, to industry, to team involvement and to leadership style. These last two factors are directly related to the project leader competencies. Picq (2011) reports four styles of leadership, as shown in Figure 1.

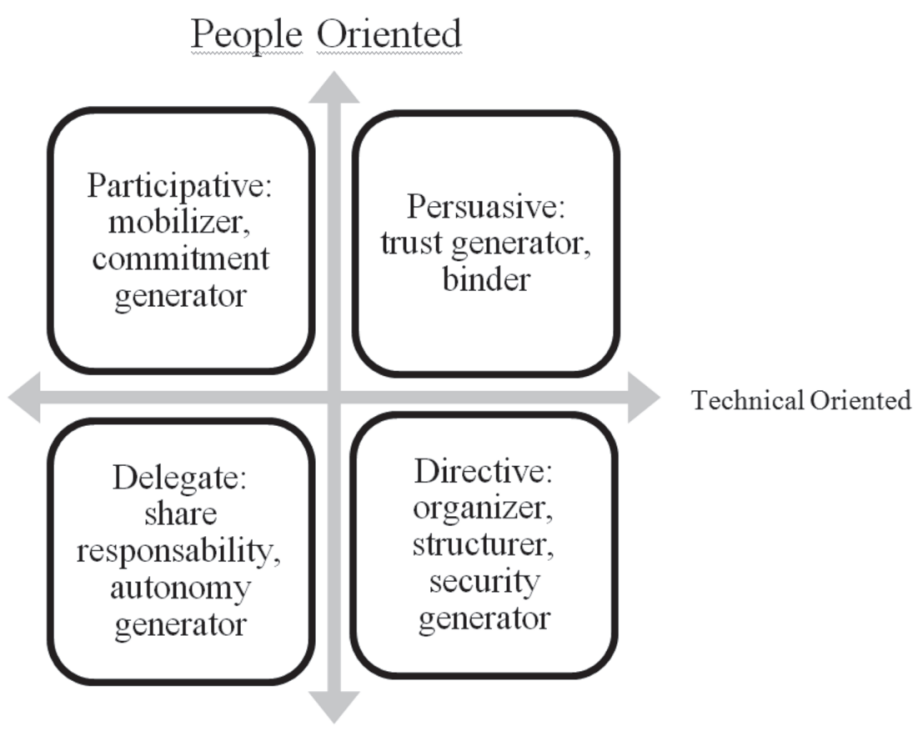

Figure 1. Project leadership styles according to Picq (2011). Source: Hersey\& Blanchard apud Picq, t. (2011). Manager Une Équipe Projet. Paris: Dunod. 
In the directive mode, the manager intervenes heavily in the organization, with a very rigid approach to methods and controls. Leaders search for effectiveness, clarity, and consistency, but can fall into authoritarianism and autocracy.

In the persuasive mode, the manager is involved in the organization, seeking understanding and taking ownership of the elements of the project structure. The persuasive leader seeks the trust of employees but may rest on paternalism and manipulation.

The participative mode assumes that the leader provides the organization's rules, and the team itself sets its rules of operation. In this mode, it is expected that the team feels like the owner and the responsible party for the rules of practice. However, this mode can slip into demagoguery or deviate from the fundamental goal.

In delegation mode, the leader assumes that the team has technical and behavior maturity to decide how to lead the project. Thus, the delegate leader encourages autonomy and responsibility of team members on the project results. This mode, however, can fall into a project without management or cohesion.

In his book, Picq (2011) also cites the need for the project managers to be flexible to change their management style according to the project evolves, for example, passing the persuasive style to the directive in a time of crisis or impasse that could lead the whole project in risk.

The project leader competencies can significantly affect projects' results (Dainty, Cheng \& Moore, 2005). In this study, the most important project leader role in the leadership, concerning the proper building of project environment, leading others, assuming authority and responsibility. The leaders should have the ability to extract the maximum from the team without the need to act in an authoritative and controlling way, maintaining emotional factors under control even in stressful situations, enabling the best use of other abilities.

Since one of the factors that most affect project performance is the leadership on the team, the project leader must take care to understand and work with these competencies to develop and move up on the competencies scale.

Thévenet, Salinesi, Etien, Gam \& Lassoued (2006) list individual and organizational factors for teams' motivation. In addition to individual factors listed by Abraham Maslow (1908-1970) and Frederick Herzberg (1913-2000), there are the factors related to empowerment and individual recognition. How organizational factors can list resources/working conditions, fair compensation and the compatibility of the company policies with the psychological characteristics and values of people.

According to Faraj \& Sambamurthy (2006), leadership must not only provide goals, instructions, and commands, but also the empowerment is fundamental in the team development. The empowerment goes through foster and facilitates the search for opportunities, new knowledge and the personal development of each team member; the encouragement and advice on interpersonal relationships, making team members seek to work together for a common goal; and a collaborative setting goals, where the leader and the team discuss the best way to evaluate the progress of activities.

Studies in Brazil such as Rabechini Jr. \& Carvalho (2003) show that, despite the project teams feel motivated by their project leaders; there is still a gap particularly regarding the development of interpersonal relationships and conflict management. It shows that there is an opportunity to build a deeper empathy between project leaders and their subordinates, allowing the use more adequate knowledge about the personal competencies and motivational factors as sources of ideas for conflict solution.

\subsection{Responsibilities of Six Sigma project leaders}

Trad \& Maximian (2009) carried out quantitative analysis of the critical success factors of Six Sigma programs, which highlights 
the importance of leadership, training, communication and review, management process, profile of the Black Belt's, teamwork and of previous initiatives on quality. However, even this study having a quantitative approach does not allow investigating the relative importance of these factors or even the effect of each of them on the projects or programs results. Galvani \& Carpinetti (2013) compared for industrial and service companies, the effect of the critical success factors of literature such as the profile of the Black Belt, project teams, the connection with the client, the nature and availability of data, the application of tools and techniques, and the time of execution of projects. However, these studies, although demonstrating that there is an impact of the project leader's profile, they did not detail the features of behavior competencies of project leaders and the impact on the success.

Given the gap in Six Sigma literature on projects leaders' desired competencies, this article aims to identify the behavioral competencies of Six Sigma projects leaders in Latin America, both described in the literature concerning project managers in general, and in the Six Sigma projects context, analyzing which are the most significant behavioral competencies in Six Sigma projects' performance.

\section{Research methods}

In this article, we reviewed 225 Six Sigma projects carried out in Brazil, Chile and Colombia of different sectors. The project success is a proxy for evaluating project leaders' performance. There are discussions in the literature related to the definition of project success. The most common, refer to the completion on time, on the quality specification, the customer acceptance, and no rework (Kerzner, 1998; Tukel \& Rom, 2001). In this study, a successful Six Sigma project must fill the following criteria: the achievement of goals, measured by its performance indicator, the achievement of goals, customer satisfaction and compliance with the deadlines. The projects that attended all these requirements were classified as successful projects; the projects that did not meet any of these requirements were considered failures, and this measure of success vs. failure was attributed to project leaders as a measure of its performance.

According to Snee (2001), an intrinsic feature of Six Sigma projects is that the goals of the Six Sigma projects are always linked to a performance indicator of the improved process, being this indicator the way of measuring the improvement has been indeed achieved. Therefore, depending on the improved process for each project, there is a performance indicator related to time, cost or quality that is the success measurement of each initiative. In this study, the project performance was measured twelve months after solution implementation, i.e., project closure. After this period, we conducted a one-sample t-test comparing the results of the indicator of this period with the goal proposed for the project, using the following hypothesis:

HO: mean of the indicator after the project is equal to the goal

H1: mean of the indicator after the project is worse than the goal (greater in the case of projects aimed at the reduction of the indicator, less in the case of projects aimed at increasing the indicator)

The t-test is applicable to this case, because the performance indicator in the first 12 months post project is a sample of all results of this indicator after its completion, and object of the test is to verify if this sample data shows that the indicator values are equal or better than the goal within a confidence interval. The assumption that the project left a stable process, generating a performance indicator that behaves adherent to a normal distribution, which was checked for all cases, a sample t-test is applicable to the assessment of the achievement of the goal. 
For projects whose P-value in a sample t-test was superior to $10 \%$ alpha value, a survey was conducted with the projects' Champions and with the Manager of the Six Sigma program. The research instrument consists of six items about the project development and the importance of the work of the Belt to the achievement of the goals, applying a five points scale. In the leaders' evaluation was performed based on the following issues:

a) Appropriate use of Six Sigma: use of the Six Sigma concepts, adherence to the DMAIC methodology and contribution of Six Sigma tools to the solution of the project problem and for process improvement.

b) Commitment and dedication of the Belt during the project: the time devoted to the project was the effectively planned, participation in the meetings with the team, Champions, and Executive presentations.

c) The contribution of the Belt to the goals achievement: how much of the improvements can be assigned to the project and what the rate of improvement actions completed by the end of the project.

The Champions and managers answered questions with alternatives in Lickert scale of 1 to 5 levels of agreement. Projects with an average exceeding 3.5 in this evaluation of satisfaction were considered approved. In addition, we verified the agreed deadlines. The successful projects in these three criteria were classified as approved projects. The projects' financial benefits were not used for project evaluation, because the minimum goals benefit varied according to the company in which projects were conducted; moreover, we did not have a direct financial benefit for all projects: many of them were oriented to customer satisfaction and to increasing or reducing risks.

Each of the 191 leaders were submitted to the Predictive Index (PI), which is a selfassessment measure that allows measuring and reporting the professional behavior of the adult population (Harry et al., 2010) since this was the tool adopted by the organizations studied.

\section{I $\mathrm{PI}^{\circ}$ as an instrument for measurement of competencies}

The Predictive Index $\left(P I^{\circ}\right)$ is an instrument consisting of two pages, filled in paper or in electronic form, in which the leader should choose among 86 options presented. Herein, the leaders in analysis select what words better describe who they are and how other people expect them to behave. Based on the analysis of the words chosen, the Predictive Index $\left(\mathrm{PI}^{\circ}\right)$ measures four primary and two secondary factors: factor $\mathrm{A}$ (dominance), factor B (extroversion), factor C (patience), factor $\mathrm{D}$ (formality), Factor $\mathrm{M}$ (energy) and factor $\mathrm{E}$ (decision-making) (Everton, 1999).

This instrument has reviews by internal consistency reliability, reliability per test and retest and validation of the constructs of the factors by correlation with other validated psychological assessment instrument, the 16PF (Everton, 1999; Perry \& Lavori, 1983).

The description of the each factor for behavioral competencies depends on a cumulative scale, measured in accordance with the deviation from the average. As the individual moves away from the mean of the factor, accumulate positive and negative characteristics as can be described in Table 4.

The instrument also allows evaluating the interaction between factors, which promotes the analysis of other secondary behavioral traits, as described in Table 5. 


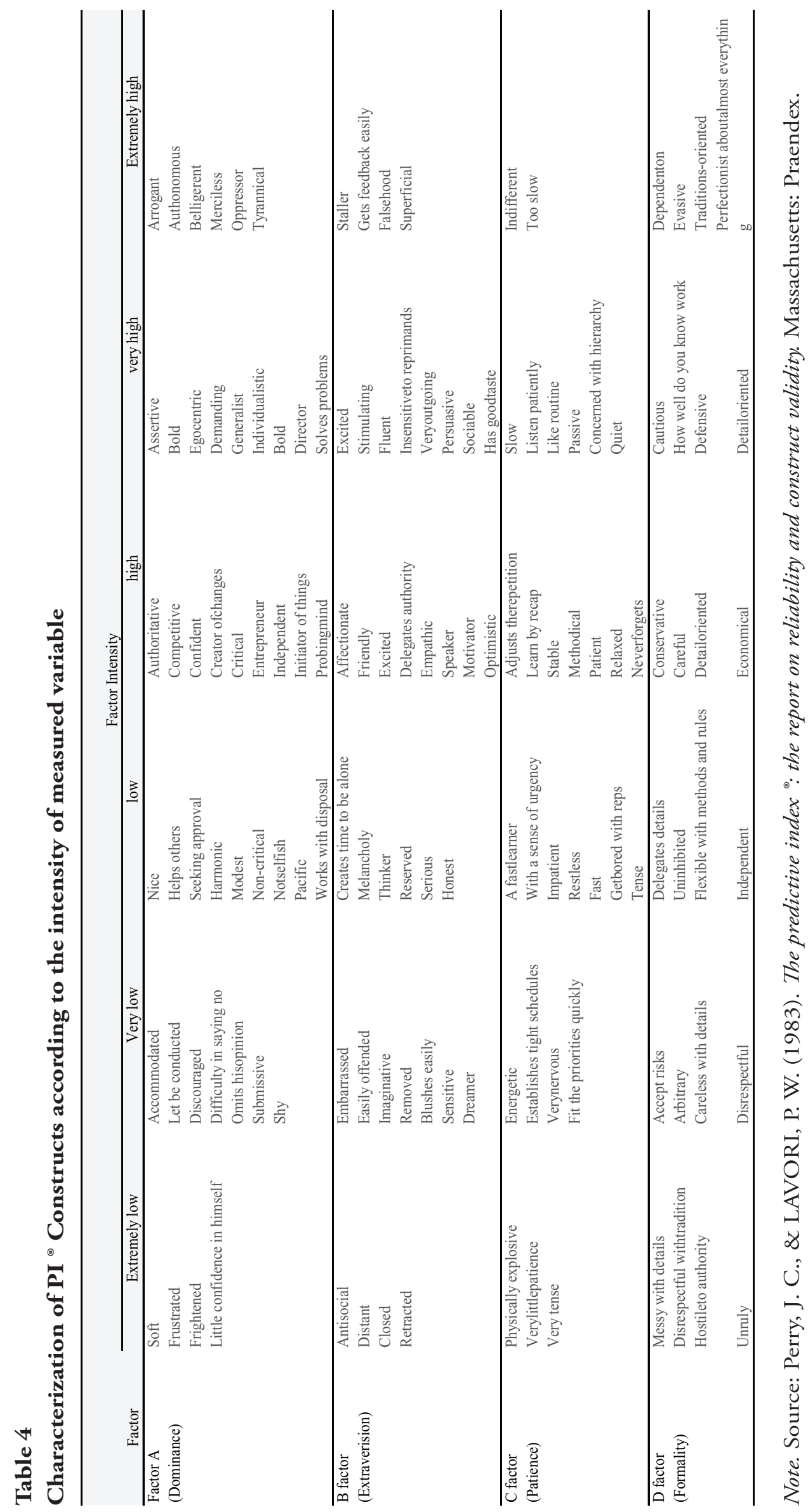


Table 5

Identification of the main emphases of factors interaction

\begin{tabular}{|c|c|c|c|}
\hline Factor 1 & Factor 2 & Factor $1>$ Factor 2 & Factor 2>Factor 1 \\
\hline $\begin{array}{l}\text { Dominance } \\
\text { (A Factor) }\end{array}$ & $\begin{array}{l}\text { Extroversion } \\
\text { (B Factor) }\end{array}$ & $\begin{array}{l}\text { Technically oriented: prioritizes his interest in } \\
\text { understanding things and processes }\end{array}$ & $\begin{array}{l}\text { Socially-driven: prioritizes his } \\
\text { understanding people }\end{array}$ \\
\hline $\begin{array}{l}\text { Dominance } \\
\text { (A Factor) }\end{array}$ & $\begin{array}{l}\text { Patience } \\
\text { (C Factor) }\end{array}$ & $\begin{array}{l}\text { Proactive: take the initiative to promote } \\
\text { changes before they are requested }\end{array}$ & $\begin{array}{l}\text { Reactive: expects guidelines } \\
\text { before initiating changes }\end{array}$ \\
\hline $\begin{array}{l}\text { Dominance } \\
\text { (A Factor) }\end{array}$ & $\begin{array}{l}\text { Formality } \\
\text { (D Factor) }\end{array}$ & $\begin{array}{l}\text { Strategic: seeks to understand the vision of the } \\
\text { whole. When the factor is above } \\
\text { average and below average factor D, is } \\
\text { considered a negotiator }\end{array}$ & Tactical: addresses the issues from their details \\
\hline $\begin{array}{l}\text { Extroversion } \\
\text { (B Factor) }\end{array}$ & $\begin{array}{l}\text { Patience } \\
\text { (C Factor) }\end{array}$ & $\begin{array}{l}\text { Rapid communication: starts contact } \\
\text { quickly and and easy communication with new } \\
\text { people }\end{array}$ & $\begin{array}{l}\text { Slow communication: waits for the touch of } \\
\text { people and expect to get used to them before } \\
\text { you approach them in communicating }\end{array}$ \\
\hline $\begin{array}{l}\text { Extroversion } \\
\text { (B Factor) }\end{array}$ & $\begin{array}{l}\text { Formality } \\
\text { (D Factor) }\end{array}$ & $\begin{array}{l}\text { Informal communication: does not use } \\
\text { formal media to communicate }\end{array}$ & $\begin{array}{l}\text { Formal communication: use of formal means to } \\
\text { communicate }\end{array}$ \\
\hline $\begin{array}{l}\text { Patience } \\
\text { (C Factor) }\end{array}$ & $\begin{array}{l}\text { Formality } \\
\text { (D Factor) }\end{array}$ & $\begin{array}{l}\text { Careless: does not } \\
\text { perform monitoring around while } \\
\text { running, waiting for the final result to manifest } \\
\text { himself }\end{array}$ & $\begin{array}{l}\text { Worried: accompanies closely the } \\
\text { execution, manifesting himself in } \\
\text { advance if realizes that the end result might } \\
\text { not come true }\end{array}$ \\
\hline
\end{tabular}

Note. Source: Perry, J.C., \& Lavori, P.W. (1983). The predictive index : the report on reliability and construct validity. Massachusetts: Praendex.

\subsection{Comparison between of PI ${ }^{\circ}$ constructs and project management competencies}

After getting the results of main factors measured by the $\mathrm{PI}^{\oplus}$, Six Sigma project leaders of the study were classified according to two perspectives. Initially, a link between the desired characteristics for a project leader (Strang, 2007) and the factors measured by the $\mathrm{PI}^{\odot}$ (Perry $\&$ Lavori, 1983) was made, as shown in Table 6.

Table 6

List of desired characteristics for a project leader (Strang, 2007) and the factors measured by the PI ${ }^{\circledR}$ (Perry \& Lavori, 1983)

\begin{tabular}{|c|c|c|}
\hline Leadership Features & PI® related factors & Characteristics \\
\hline Innovative (creative solution to problems, adaptation) & $\begin{array}{l}\text { Factor A aboveaverage } \\
\text { Factor A bigger than factor B } \\
\text { Factor C belowaverage } \\
\text { Factor D belowaverage }\end{array}$ & $\begin{array}{l}\text { Creator, probing mind, initiator of things } \\
\text { prioritizes your interest in } \\
\text { understanding things and processes } \\
\text { a fastlearner } \\
\text { questioning methods and rules, flexible }\end{array}$ \\
\hline & $\begin{array}{l}\text { Factor A aboveaverage } \\
\text { Factor B aboveaverage }\end{array}$ & $\begin{array}{l}\text { assertive, confident, Director } \\
\text { empathic, persuasive, motivator }\end{array}$ \\
\hline Broker (power, influence, resource acquisition) & Factor D belowaverage & flexible, independent \\
\hline $\begin{array}{l}\text { Facilitator (conflict management, participatory decision } \\
\text { making) }\end{array}$ & $\begin{array}{l}\text { Factor A aboveaverage } \\
\text { Factor B aboveaverage }\end{array}$ & $\begin{array}{l}\text { Director, solves problems } \\
\text { friendly, empathetic, otimesta, motivator }\end{array}$ \\
\hline Mentor (development) & $\begin{array}{l}\text { Factor A aboveaverage } \\
\text { Factor B aboveaverage }\end{array}$ & $\begin{array}{l}\text { critical, demanding } \\
\text { delegates authority, stimulant }\end{array}$ \\
\hline Coordinator (coordination of tasks, budget control) & $\begin{array}{l}\text { Factor A aboveaverage } \\
\text { Factor D aboveaverage }\end{array}$ & $\begin{array}{l}\text { critical, demanding } \\
\text { economical, conservative, careful }\end{array}$ \\
\hline Monitor (information management, critical thinking) & $\begin{array}{l}\text { Factor A bigger than factor B } \\
\text { B factor belowaverage }\end{array}$ & $\begin{array}{l}\text { prioritizes his interest in } \\
\text { understanding things and processes } \\
\text { seriously, imaginative thinker }\end{array}$ \\
\hline Producer (productivity, efficiency) & $\begin{array}{l}\text { Factor A aboveaverage } \\
\text { Factor A bigger than factor B } \\
\text { Factor D aboveaverage } \\
\end{array}$ & $\begin{array}{l}\text { critical, demanding } \\
\text { prioritizes his interest in } \\
\text { understanding things and processes } \\
\text { economical, conservative, careful }\end{array}$ \\
\hline Director (Planner, goals) & $\begin{array}{l}\text { Factor } \mathrm{A} \text { aboveaverage } \\
\text { Factor } \mathrm{C} \text { belowaverage }\end{array}$ & $\begin{array}{l}\text { entrepreneur, Director } \\
\text { sense of urgency, adjusts priorities quickly }\end{array}$ \\
\hline
\end{tabular}

Note. Source Strang, K. D. (2007). Examining effective technology project leadership traits and behaviors. Computers In Human Behavior, 23(1), 424-462; Perry, j. c., \& Lavori, p. w. (1983). The predictive index ${ }^{\circledR}$ : the report on reliability and construct validity. Massachusetts: Praendex. 
According to Table 6, the project leader has a specific technical and managerial leadership competence, if the leader fit the most factors related to that given competence; if less than half of the factors of $\mathrm{PI}^{\oplus}$ related to a specific competence is not possessed by state in Table 6, the leader did not have leadership competence.

In addition, a second classification compares the characteristics measured by PI ${ }^{\odot}$
(Perry \&Lavori, 1983) with the leadership model (Picq, 2011). The relation of the characteristics of the behavioral profile with the leadership model is described in Table 7.

Data were organized based on the following variables: the sector of the company, the type of project (Green Belt or Black Belt), the gender of the leader, behavioral profile classification, and project success or failure.

Table 7

Relationship between the Leadership Model (Picq, 2011) and the factors of PI ${ }^{\circledR}$ (Perry, \& Lavori, 1983)

\begin{tabular}{|c|c|c|c|}
\hline \multirow{7}{*}{ 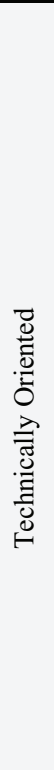 } & \multirow{6}{*}{$\stackrel{\sqrt{60}}{\text {.017 }}$} & \multicolumn{2}{|c|}{ People oriented } \\
\hline & & Low & High \\
\hline & & Participative leadership & Persuasive leadership \\
\hline & & $\begin{array}{l}\text { Factor B above average (affectionate, friendly, } \\
\text { sociable) } \\
\text { Factor D below average (delegator, flexible) }\end{array}$ & $\begin{array}{l}\text { Factor A above } \\
\text { average (assertive, demanding, Director) } \\
\text { Factor B above average (stimulating, } \\
\text { enthusiastic, persuasive) }\end{array}$ \\
\hline & & & $\begin{array}{l}\text { Factor D below } \\
\text { average (flexible, informal), but greater } \\
\text { than C Factor (worried: accompanies closel } \\
\text { y the execution, manifesting himself in } \\
\text { advance if provides that the end result might } \\
\text { not come true) }\end{array}$ \\
\hline & & Delegative leadership & Directive leadership \\
\hline & 3 & $\begin{array}{l}\text { B factor below average (reserved, thinker, distant) } \\
\text { Factor D below average (delegator, flexible) }\end{array}$ & $\begin{array}{l}\text { Factor A above } \\
\text { average (authoritarian, critical, demanding) } \\
\text { B factor below } \\
\text { average (serious, honest, thinker) } \\
\text { Factor D above } \\
\text { average (careful, concerned, Centralizer) }\end{array}$ \\
\hline
\end{tabular}

Note. Source: Picq, t. (2011). Manager une équipe projet. Paris: Dunod. Perry, j. c., \& Lavori, p. w. (1983). The predictive index ${ }^{\oplus}$ : the report on reliability and construct validity. Massachusetts: Praendex.

The PI ${ }^{\oplus}$ measures other aspects besides the tabulated in tables 6 and 7 , which are determined by the intensity of the factors, as well as for other combinations of factors not described in this article, for a limited space. The authors have chosen to treat only, in the statistics, factors, and combinations congruent with the constructs of project leaders competencies described in the literature review.

Initially, descriptive statistics were analyzed, for the purpose of characterization of the study population.

Then, Chi-square tests were performed for verification of the relation between the projects' success and behavioral competencies. The Chi-square test is a technique which allows verifying the frequency of events are independent of any other categorical independent variables, for discrete events, as is the case of successes and failures of projects, (Hair Jr., Black, Babin, Anderson \& Tatham, 2009).

Chi-Square test for independence is given by the maximum likelihood estimators of $P i$. and P.j are:

$$
\begin{array}{ll}
\hat{p}_{i .}=\frac{n_{i .}}{n}, & i=1, \ldots, r \\
\hat{p}_{. j}=\frac{n_{. j}}{n}, & j=1, \ldots, c
\end{array}
$$


So if the independence hypothesis is valid, the maximum likelihood estimators of $P i j$ are:

$$
\hat{p}_{i j}=\hat{p}_{i .} \times \hat{p}_{. j}=n \frac{n_{i .}}{n} \frac{n_{. j}}{n}=\frac{n_{i .} n_{. j}}{n} \quad \begin{aligned}
& i=1, \ldots, r \\
& j=1, \ldots, c
\end{aligned}
$$

and the likelihood estimators of expected frequencies $E_{i j}$ are:

$$
\begin{gathered}
E_{i j}=n \frac{n_{i .}}{n} \frac{n_{. j}}{n}=\frac{n_{i .} n_{. j}}{n} \quad \begin{array}{l}
i=1, \ldots, r \\
j=1, \ldots, c
\end{array} \\
O_{i j}=\left(O_{11}, O_{12}, \ldots, O_{r c}\right) \text { is the vector of }
\end{gathered}
$$
observed counts with multinomial distribution, and $E_{i j}$ represents the expected frequencies and assumes valid the hypothesis of independence of classification criteria, the statistics

$$
Q_{o b s}^{2}=\sum_{i=1}^{r} \sum_{j=1}^{c} \frac{\left(O_{i j}-E_{i j}\right)^{2}}{E_{i j}}
$$

has asymptotic Chi-square distribution with $(r-$ 1) $(c-1)$ degrees of freedom.

The $X^{2}$ statistics allow understanding what the critical region of the independence test. When there is not independence, it is natural that the observed frequencies $O_{i j}$ are significantly different from the expected frequency $E_{i j}$ when independence occurs. Thus, we must reject the hypothesis $H_{O}$ of independence of classification criteria when the $Q^{2}$ obs statistic is greater than a critical point $X^{2}{ }_{\alpha}$ by using the Chi-square distribution table.

So, given a level of $\alpha$ significance, the $\mathrm{p}$-value is determined by $\mathrm{p}$-valor $=\mathrm{P}\left[Q^{2}{ }_{o b s}>X_{\alpha}^{2}\right.$; $\left.(r-1)(c-1) \mid H_{O}\right]$.

After the application of statistical techniques, we checked whether the findings reflect the study hypothesis. In addition, the results were submitted to a logistic regression analysis to create a predictive model of success of projects. Second Hair Jr. et al. (2009), the logistic regression model allows the measurement of the probability of occurrence of an event and the identification of the characteristics of the elements belonging to each category established by the dichotomy of the dependent variable. A logistic regression model is used for an explanatory variable project success or failure. In this case, there is a sample of $\mathrm{n}=191$ projects' leaders independent of $\left(x_{i}, m_{i}, y_{i}\right) ; i=1,2, \ldots, n$, as follows:

- $x_{i}$ is the value of the explanatory variable, in this case, the success rate;

- $m_{i}$ is the number of checked items in the sample (number of projects);

- $y_{i}$ is the number of successful projects

- $\quad$ in $m_{i}$ projects conducted; and

- $n$ is the total of projects conducted.

Thus, we assume that the response variable has binomial probability distribution $Y_{i \sim B}\left(m_{i}, \pi_{i}\right)$, such that

$$
P\left[Y_{i}=y_{i}\right]=\left(\begin{array}{c}
m_{i} \\
y_{i}
\end{array}\right) \pi_{i}^{y_{i}}\left(1-\pi_{i}\right)^{m_{i}-y_{i}}
$$

To adjust the mean response to the linear model use the function

$$
\pi\left(x_{i}\right)=\frac{e^{\beta_{0}+\beta_{1} x_{i}}}{1+e^{\beta_{0}+\beta_{1} x_{i}}}, i=1, \ldots, n,
$$

which can be written as

$$
\ln \left(\frac{\pi_{i}}{1-\pi_{i}}\right)=\beta_{0}+\beta_{1} x_{i}
$$

\section{Results}

Initially, the projects were analyzed according to project type, the leader gender, company sector, and the projects' result, as shown in Table 8. Then, project leaders were classified in accordance with the tables 6 and 7 , generating the results tabulated in Table 9A-B. 
Table 8

Classification of projects regarding typology, gender and industry

\begin{tabular}{|c|c|c|c|}
\hline \multicolumn{4}{|c|}{ Project result } \\
\hline Project Type & unsuccessful & successful & Total \\
\hline GB & 48 & 53 & 101 \\
\hline $\mathrm{BB}$ & 37 & 117 & 154 \\
\hline Total & 85 & 170 & 255 \\
\hline Gender & unsuccessful & successful & Total \\
\hline Male & 65 & 128 & 193 \\
\hline Female & 20 & 42 & 62 \\
\hline Total & 85 & 170 & 255 \\
\hline Sector & unsuccessful & successful & Total \\
\hline Manufacturing & 7 & 37 & 44 \\
\hline Service Operations & 78 & 133 & 211 \\
\hline Total & 85 & 170 & 255 \\
\hline
\end{tabular}

Table 9A

Classification of project leaders according to behavioral competencies

\begin{tabular}{|c|c|c|c|c|c|c|c|}
\hline \multicolumn{4}{|c|}{ Inovator Behavior } & \multicolumn{4}{|c|}{ Producer Behavior } \\
\hline Type & absent & present & Total & Type & absent & present & Total \\
\hline$\overline{\text { GB }}$ & 81 & 20 & $\overline{101}$ & $\overline{\mathrm{GB}}$ & 58 & 43 & $\overline{101}$ \\
\hline $\mathrm{BB}$ & 86 & 68 & 154 & $\mathrm{BB}$ & 87 & 67 & 154 \\
\hline Total & 167 & 88 & 255 & Total & 145 & 110 & 255 \\
\hline \multicolumn{4}{|c|}{ Broker Behavior } & \multicolumn{4}{|c|}{ Director Behavior } \\
\hline Type & absent & present & Total & Type & absent & present & Total \\
\hline GB & 85 & 16 & $\overline{101}$ & GB & 32 & 69 & $\overline{101}$ \\
\hline $\mathrm{BB}$ & 110 & 44 & 154 & $\mathrm{BB}$ & 14 & 140 & 154 \\
\hline Total & 195 & 60 & 255 & Total & 46 & 209 & 255 \\
\hline \multicolumn{4}{|c|}{ Facilitator/ Mentor Behavior } & \multicolumn{4}{|c|}{ Persuasive leadership } \\
\hline Type & absent & present & Total & Type & absent & present & Total \\
\hline$\overline{\text { GB }}$ & 76 & 25 & 101 & $\overline{\mathrm{GB}}$ & 87 & 14 & 101 \\
\hline $\mathrm{BB}$ & 99 & 55 & 154 & $\mathrm{BB}$ & 105 & 49 & 154 \\
\hline Total & 175 & 80 & 255 & Total & 192 & 63 & 255 \\
\hline \multicolumn{4}{|c|}{ Coordinator behavior } & \multicolumn{4}{|c|}{ Participative leadership } \\
\hline Type & absent & present & Total & $\overline{\text { Type }}$ & absent & present & Total \\
\hline GB & 53 & 48 & 101 & GB & 81 & 20 & 101 \\
\hline $\mathrm{BB}$ & 84 & 70 & 154 & $\mathrm{BB}$ & 109 & 45 & 154 \\
\hline Total & 137 & 118 & 255 & Total & 190 & 65 & 255 \\
\hline \multicolumn{4}{|c|}{ Monitor behavior } & \multicolumn{4}{|c|}{ Delegate leadership } \\
\hline Type & absent & present & Total & Type & absent & present & Total \\
\hline$\overline{\text { GB }}$ & 41 & 60 & $\overline{101}$ & $\overline{\mathrm{GB}}$ & 89 & 12 & $\overline{101}$ \\
\hline $\mathrm{BB}$ & 63 & 91 & 154 & $\mathrm{BB}$ & 122 & 32 & 154 \\
\hline \multirow[t]{6}{*}{ Total } & 104 & 151 & 255 & Total & 211 & 44 & 255 \\
\hline & & & & \multicolumn{4}{|c|}{ Directive leadership } \\
\hline & & & & Type & absent & present & Total \\
\hline & & & & $\overline{\mathrm{GB}}$ & 62 & 39 & $\overline{101}$ \\
\hline & & & & $\mathrm{BB}$ & 95 & 59 & 154 \\
\hline & & & & Total & 157 & 98 & 255 \\
\hline
\end{tabular}


Table 9B

Classification of project leaders based on the behavior as Project Manager

\begin{tabular}{|c|c|c|c|}
\hline \multicolumn{4}{|c|}{ Projects Results } \\
\hline & & failure & success \\
\hline \multirow{2}{*}{ Inovator Behavior } & absent & 64 & 103 \\
\hline & present & 21 & 67 \\
\hline
\end{tabular}

\begin{tabular}{|c|c|c|c|}
\hline \multicolumn{4}{|c|}{ Projects Results } \\
\hline & & failure & success \\
\hline \multirow[t]{2}{*}{ Director Behavior } & absent & 24 & 22 \\
\hline & present & 61 & 148 \\
\hline
\end{tabular}

\begin{tabular}{lcrr}
\hline \multicolumn{4}{c}{ Projects Results } \\
& & failure & \multicolumn{2}{c}{ success } \\
\hline Broker Behavior & absent & 70 & 125 \\
& present & 15 & 45 \\
\hline
\end{tabular}

\begin{tabular}{|c|c|c|c|}
\hline \multicolumn{4}{|c|}{ Projects Results } \\
\hline & & failure & success \\
\hline \multirow[t]{2}{*}{ Persuasive leadership } & absent & 70 & 122 \\
\hline & present & 15 & 48 \\
\hline
\end{tabular}

\begin{tabular}{lccr}
\hline \multicolumn{4}{c}{ Projects Results } \\
\hline & & failure & \multicolumn{2}{c}{ success } \\
\hline Facilitator/ Mentor Behavior & absent & 63 & 112 \\
& present & 22 & 58 \\
\hline
\end{tabular}

\begin{tabular}{|c|c|c|c|}
\hline \multicolumn{4}{|c|}{ Projects Results } \\
\hline & & failure & success \\
\hline \multirow[t]{2}{*}{ Participative leadership } & absent & 67 & 123 \\
\hline & present & 18 & 47 \\
\hline
\end{tabular}

\begin{tabular}{lccr}
\hline \multicolumn{4}{c}{ Projects Results } \\
& & & \\
\hline & failure & \multicolumn{2}{c}{ success } \\
\hline Coordinator behavior & absent & 47 & 90 \\
& present & 38 & 80 \\
\hline
\end{tabular}

\begin{tabular}{lccr}
\hline \multicolumn{4}{c}{ Projects Results } \\
\hline & failure & \multicolumn{2}{c}{ success } \\
\hline Monitor behavior & absent & 34 & 70 \\
& present & 51 & 100 \\
\hline
\end{tabular}

\begin{tabular}{|c|c|c|c|}
\hline \multicolumn{4}{|c|}{ Projects Results } \\
\hline & & failure & success \\
\hline \multirow[t]{2}{*}{ Directive leadership } & absent & 54 & 103 \\
\hline & present & 31 & 67 \\
\hline
\end{tabular}

\begin{tabular}{lccc}
\hline \multicolumn{4}{c}{ Projects Results } \\
\hline & & failure & \multicolumn{2}{c}{ success } \\
\hline Producer Behavior & absent & 49 & 96 \\
& present & 36 & 74 \\
\hline
\end{tabular}

After this classification, Chi-square tests for assessment of independence were performed, applying Minitab software, where the alternative hypothesis refers to the dependency of the project performance with the factor studied.

\begin{tabular}{|c|c|c|c|}
\hline \multicolumn{4}{|c|}{ Projects Results } \\
\hline & & failure & success \\
\hline \multirow{2}{*}{ Delegate leadership } & absent & 70 & 141 \\
\hline & present & 15 & 29 \\
\hline
\end{tabular}

In tables 10, 11 and 12, are the results of the tests of independence made, with their Chisquare values calculated and P-value. 
Table 10

Independence test results for the entire sample examined

\begin{tabular}{|c|c|c|c|c|}
\hline Population & Hypothesis tested & $\begin{array}{c}\text { Calculated chi } \\
\text { squate }\end{array}$ & P-value & $\begin{array}{c}\text { Hypothesis } \\
\text { Confirmation }\end{array}$ \\
\hline \multirow{11}{*}{ 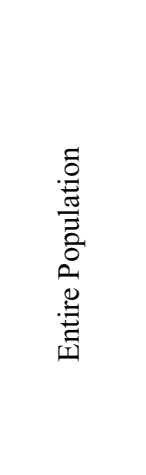 } & The performance in the project depends on innovative behaviour? & 5.422 & 0.02 & Supported \\
\hline & The performance in the project depends on broker behavior? & 2.452 & 0.117 & Unsupported \\
\hline & The performance behaviour depends on the project facilitator/mentor? & 1.785 & 0.182 & Unsupported \\
\hline & The performance in the project depends on a coordinator behavior? & 0.126 & 0.722 & Unsupported \\
\hline & The project depends on the performance of a behavior monitor? & 0.032 & 0.857 & Unsupported \\
\hline & The performance in the project depends on producer behaviour? & 0.032 & 0.858 & Unsupported \\
\hline & The performance in the project depends on Director behavior? & 8.965 & 0.003 & Supported \\
\hline & The performance in the project depends on a persuasive leadership? & 3.415 & 0.065 & Supported \\
\hline & The performance in the project depends on a participative leadership? & 1.249 & 0.264 & Unsupported \\
\hline & The performance in the project depends on a delegate leadership? & 0.014 & 0.907 & Unsupported \\
\hline & The performance in the project depends on a Directive leadership? & 0.207 & 0.649 & Unsupported \\
\hline
\end{tabular}

Table 11

Independence test results stratified by gender

\begin{tabular}{|c|c|c|c|c|}
\hline Population & Hypothesis tested & $\begin{array}{c}\text { Calculated chi } \\
\text { squate }\end{array}$ & P-value & $\begin{array}{c}\text { Hypothesis } \\
\text { Confirmation }\end{array}$ \\
\hline \multirow{11}{*}{$\frac{\frac{0}{\pi}}{\Sigma}$} & The performance in the project depends on innovative behaviour? & 5.857 & 0.016 & Supported \\
\hline & The performance in the project depends on broker behavior? & 2.24 & 0.134 & Unsupported \\
\hline & The performance behaviour depends on the project facilitator/mentor? & 1.139 & 0.286 & Unsupported \\
\hline & The performance in the project depends on a coordinator behavior? & 0.038 & 0.845 & Unsupported \\
\hline & The project depends on the performance of a behavior monitor? & 0.016 & 0.9 & Unsupported \\
\hline & The performance in the project depends on producer behaviour? & 0.157 & 0.692 & Unsupported \\
\hline & The performance in the project depends on Director behavior? & 8.508 & 0.004 & Supported \\
\hline & The performance in the project depends on a persuasive leadership? & 1.624 & 0.203 & Unsupported \\
\hline & The performance in the project depends on a participative leadership? & 1.008 & 0.315 & Unsupported \\
\hline & The performance in the project depends on a delegate leadership? & 0.101 & 0.75 & Unsupported \\
\hline & The performance in the project depends on a Directive leadership? & 0.247 & 0.619 & Unsupported \\
\hline \multirow{11}{*}{ 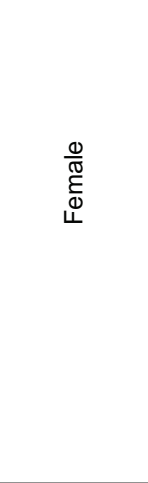 } & The performance in the project depends on innovative behaviour? & 0.198 & 0.657 & Unsupported \\
\hline & The performance in the project depends on broker behavior? & 0.283 & 0.595 & Unsupported \\
\hline & The performance behaviour depends on the project facilitator/mentor? & 0.637 & 0.425 & Unsupported \\
\hline & The performance in the project depends on a coordinator behavior? & 0.136 & 0.713 & Unsupported \\
\hline & The project depends on the performance of a behavior monitor? & 0.318 & 0.573 & Unsupported \\
\hline & The performance in the project depends on producer behaviour? & 0.114 & 0.736 & Unsupported \\
\hline & The performance in the project depends on Director behavior? & 0.716 & 0.398 & Unsupported \\
\hline & The performance in the project depends on a persuasive leadership? & 2.03 & 0.154 & Unsupported \\
\hline & The performance in the project depends on a participative leadership? & 0.233 & 0.629 & Unsupported \\
\hline & The performance in the project depends on a delegate leadership? & 0.603 & 0.438 & Unsupported \\
\hline & The performance in the project depends on a Directive leadership? & 0.003 & 0.956 & Unsupported \\
\hline
\end{tabular}


Table 12

Independence test results stratified by projects type

\begin{tabular}{|c|c|c|c|c|}
\hline Population & Hypothesis tested & $\begin{array}{c}\text { Calculated chi } \\
\text { squate }\end{array}$ & P-value & $\begin{array}{l}\text { Hypothesis } \\
\text { Confirmation }\end{array}$ \\
\hline \multirow{11}{*}{ 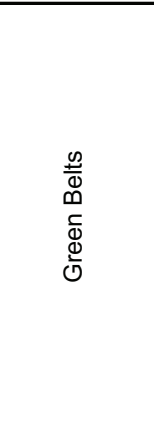 } & The performance in the project depends on innovative behaviour? & 1.569 & 0.21 & Unsupported \\
\hline & The performance in the project depends on broker behavior? & 0.109 & 0.742 & Unsupported \\
\hline & The performance behaviour depends on the project facilitator/mentor? & 0.003 & 0.956 & Unsupported \\
\hline & The performance in the project depends on a coordinator behavior? & 0.006 & 0.94 & Unsupported \\
\hline & The project depends on the performance of a behavior monitor? & 0.044 & 0.835 & Unsupported \\
\hline & The performance in the project depends on producer behaviour? & 0.052 & 0.82 & Unsupported \\
\hline & The performance in the project depends on director behavior? & 0.589 & 0.443 & Unsupported \\
\hline & The performance in the project depends on a persuasive leadership? & 0.142 & 0.706 & Unsupported \\
\hline & The performance in the project depends on a participative leadership? & 0.064 & 0.801 & Unsupported \\
\hline & The performance in the project depends on a delegate leadership? & 0.187 & 0.665 & Unsupported \\
\hline & The performance in the project depends on a directive leadership? & 0.048 & 0.827 & Unsupported \\
\hline \multirow{11}{*}{$\begin{array}{l}\frac{\infty}{\omega} \\
\infty \\
\frac{0}{0} \\
\frac{\pi}{\infty}\end{array}$} & The performance in the project depends on innovative behaviour? & 0.788 & 0.375 & Unsupported \\
\hline & The performance in the project depends on broker behavior? & 1.153 & 0.283 & Unsupported \\
\hline & The performance behaviour depends on the project facilitator/mentor? & 1.601 & 0.206 & Unsupported \\
\hline & The performance in the project depends on a coordinator behavior? & 0.474 & 0.491 & Unsupported \\
\hline & The project depends on the performance of a behavior monitor? & 0.19 & 0.663 & Unsupported \\
\hline & The performance in the project depends on producer behaviour? & 0.174 & 0.676 & Unsupported \\
\hline & The performance in the project depends on director behavior? & 5.692 & 0.017 & Supported \\
\hline & The performance in the project depends on a persuasive leadership? & 1.261 & 0.262 & Unsupported \\
\hline & The performance in the project depends on a participative leadership? & 0.565 & 0.452 & Unsupported \\
\hline & The performance in the project depends on a delegate leadership? & 1.155 & 0.283 & Unsupported \\
\hline & The performance in the project depends on a directive leadership? & 0.208 & 0.648 & Unsupported \\
\hline
\end{tabular}

Table 13

Independence test results stratified by sector

\begin{tabular}{|c|c|c|c|c|}
\hline Population & Hypothesis tested & $\begin{array}{c}\text { Calculated chi } \\
\text { squate }\end{array}$ & P-value & $\begin{array}{c}\text { Hypothesis } \\
\text { Confirmation }\end{array}$ \\
\hline \multirow{11}{*}{ 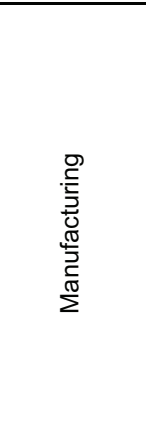 } & The performance in the project depends on innovative behaviour? & 0.04 & 0.841 & Unsupported \\
\hline & The performance in the project depends on broker behavior? & 0.218 & 0.64 & Unsupported \\
\hline & The performance behaviour depends on the project facilitator/mentor? & 0.661 & 0.416 & Unsupported \\
\hline & The performance in the project depends on a coordinator behavior? & 0.724 & 0.395 & Unsupported \\
\hline & The project depends on performance of a behavior monitor? & 0.459 & 0.498 & Unsupported \\
\hline & The performance in the project depends on producer behaviour? & 0.023 & 0.88 & Unsupported \\
\hline & The performance in the project depends on Director behavior? & $\mathrm{N} / \mathrm{A}$ & N/A & $*$ \\
\hline & The performance in the project depends on a persuasive leadership? & 1.019 & 0.313 & Unsupported \\
\hline & The performance in the project depends on a participative leadership? & 0.218 & 0.64 & Unsupported \\
\hline & The performance in the project depends on a delegative leadership? & $\mathrm{N} / \mathrm{A}$ & $\mathrm{N} / \mathrm{A}$ & $*$ \\
\hline & The performance in the project depends on a Directive leadership? & 0.17 & 0.68 & Unsupported \\
\hline \multirow{11}{*}{ 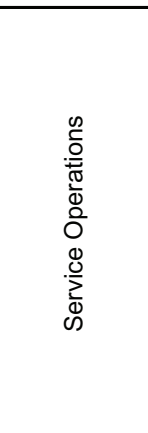 } & The performance in the project depends on innovative behaviour? & 6.236 & 0.013 & Supported \\
\hline & The performance in the project depends on broker behavior? & 1.314 & 0.252 & Unsupported \\
\hline & The performance behaviour depends on the project facilitator/mentor? & 2.049 & 0.152 & Unsupported \\
\hline & The performance in the project depends on a coordinator behavior? & 0.157 & 0.692 & Unsupported \\
\hline & The project depends on performance of a behavior monitor? & 0.094 & 0.759 & Unsupported \\
\hline & The performance in the project depends on producer behaviour? & 0.004 & 0.952 & Unsupported \\
\hline & The performance in the project depends on Director behavior? & 6.326 & 0.012 & Supported \\
\hline & The performance in the project depends on a persuasive leadership? & 5.212 & 0.022 & Supported \\
\hline & The performance in the project depends on a participative leadership? & 0.51 & 0.475 & Unsupported \\
\hline & The performance in the project depends on a delegative leadership? & 0.035 & 0.851 & Unsupported \\
\hline & The performance in the project depends on a Directive leadership? & 0.001 & 0.978 & Unsupported \\
\hline
\end{tabular}

Note. * It was not possible to test the hypothesis due to imbalance of count data between categories 
As mentioned in Section 3, there are factors measured by the instrument $\mathrm{PI}{ }^{\oplus}$ that are not exactly corresponding to the factors listed in the literature, and there is an interest in predicting the project leaders who present greater chances of project success. Thus, logistic regressions, applying Minitab software, considering the factors listed in
Table 4 and Table 5 for the prediction of success in projects was performed. Table 14 shows the logistic regression model, built from the full set of projects. Table 15 shows the model considering only the Green Belt projects and Table 16 shows the model considering the Black Belt projects.

Table 14

Logistic regression model to predict the success of projects, considering all typologies

\begin{tabular}{|c|c|c|c|c|c|}
\hline Predictor & Coefficient & P-value (variable) & Odd Ratio & P-value (model) & Log-Likelihood \\
\hline Constant & 0.073 & 0.768 & & 0.001 & -155.018 \\
\hline Factor C (patience) & -0.427 & 0.055 & 0.65 & & \\
\hline Factor $\mathrm{D}>$ Factor C (preocupation) & 0.506 & 0.024 & 1.66 & & \\
\hline Factor $\mathrm{A}$ above average and factor $\mathrm{D}$ below average (negotiator) & 0.336 & 0.038 & 1.4 & & \\
\hline \multicolumn{6}{|l|}{$\underline{\text { Fit Tests }}$} \\
\hline Method & Chi-Square & P-value & & & \\
\hline Pearson & 4.677 & 0.197 & & & \\
\hline Deviance & 5.655 & 0.13 & & & \\
\hline Hosmer-Lemeshow & 0.173 & 0.678 & & & \\
\hline
\end{tabular}

Table 14 shows that, as factor $\mathrm{C}$ (patience) grows, the likelihood of project success decreases. Moreover, the increased difference between factors D and C (Concern) increases the project success likelihood and the presence of negotiation characteristic (Factor A high and factor D low) also contribute to the increased project success likelihood.

\section{Table 15}

Logistic regression model of the probability of success of the projects, considering only the universe of Green Belt projects

\begin{tabular}{|c|c|c|c|c|c|}
\hline Predictor & Coefficient & P-value (variable) & Odd Ratio & P-value (model) & Log-Likelihood \\
\hline Constant & -0.087 & 0.75 & & 0.035 & -67.258 \\
\hline Factor D $>$ Factor C (preocupation) & 0.809 & 0.032 & 2.24 & & \\
\hline Factor A above average and factor D below average (negotiator) & 0.703 & 0.038 & 2.02 & & \\
\hline \multicolumn{6}{|l|}{$\underline{\text { Fit Tests }}$} \\
\hline Method & \multicolumn{3}{|c|}{ Chi-Square P-value } & & \\
\hline Pearson & 1.205 & 0.272 & & & \\
\hline Deviance & 1.853 & 0.173 & & & \\
\hline Hosmer-Lemeshow & 0.266 & 0.606 & & & \\
\hline
\end{tabular}

Table 14 confirms some of the findings in the previous analysis: the increase in the difference between factors D and C (Concern) and negotiation characteristics increases project success likelihood.

Table 15

Logistic regression model for the probability of success of the projects, considering only the universe of Black Belt projects

\begin{tabular}{|c|c|c|c|c|c|}
\hline Predictor & Coefficient & P-value (variable) & Odd Ratio & P-value (model) & Log-Likelihood \\
\hline Constant & 0.444 & 0.189 & & 0.012 & -81.735 \\
\hline Factor A (Dominance) & 0.849 & 0.012 & 2.34 & & \\
\hline
\end{tabular}


Note that there are differences between the predictors of success depending on the set of projects reviewed. Table 15 shows that, for Black Belt projects, critical issue in the successful projects prediction is the factor A (dominance), i.e. in the presence of project leaders with high dominance, the success rate of projects increases.

\section{Discussion}

The set of projects analyzed brought a comprehensive panorama, allowing to verify the research hypothesis. The results show that only the "innovative" and "director" behaviors competencies have a significant effect on projects success.

According to Strang (2007), the innovative behavior is characterized by the ability to adapt and adopt creative solutions to problems, being characterized by a leader with an open mind and powered by intellectual stimuli. In Six Sigma projects, the need to adapting Six Sigma tools to practical problems, as well as the need to tackle a project with solution unknown a priori, can explain why this factor rises significantly on the results of the projects.

According to Strang (2007), leadership focused on performance to achieve organizational goals is aligned with the Director planning and adaptation function of the tasks and deliverables of the team members. This was another factor that resulted in significant statistical tests, which emphasizes the importance to the Six Sigma project leader to ensure that each task performed in the project must have a purpose aligned with the project goal and project's success, related to financial results from quantitative goals.

Gender differences were identified in innovative and Director factors, being significant for male and not for female. Such a difference can be explained by the small sample size for the female gender, which reduces the power of comparison between categories. The same was verify for sectors analyzed - industry and services. However, for persuasive leadership factor (Picq, 2011); the service sector presents significant differences compared to the general population. This result can be explained due to the lack of background of service companies on continuous improvement and statistical process control concepts, if compared with industry, demanding for project's leaders a better negotiation and persuasion ability for implementing such practices.

The logistic regression predictive models allow exploring the project leaders' competencies that are not well explored in project management literature. In general, Factor C, project leader patience, is significant, and the combination of factors D and C, i.e., the project leader concerns in following all project details, and the presence of negotiation characteristic.

The Factor C, project leader patience, emerges from this study, indicating that the nature of the Six Sigma projects, with their limited period and great pressure for short-term return privileges project leaders with competencies that stimulate agile responsiveness.

The combination of concern characteristic (emphasis of combination of factors D and C), and the negotiation characteristic (the Factor A above-average and Factor D below-average), emphasizes the project leader ability of being strategic, analyzing the comprehensive scenario and delegating the execution of tasks but at the same time keeping control of the project scope to ensure the result.

Dominance (Factor A) appears as critical to Black Belt projects and is related to the fact that the Black Belt's leave their usual functions to develop the role of full-time project leader. Thus, $\mathrm{BBs}$ have a leading role without have a power position because the project structure is ad hoc, which requires leadership competencies. 


\section{Conclusions, recommendations, and limitations of the study}

This study shows that some of the behavioral competencies required of the Six Sigma projects' leaders are similar to those recommended in PM literature to project managers. However, some behavioral competencies suggested in the literature could not be verified, which may be due to the singular feature of Six Sigma projects, such as short duration, focused on technical aspects of the process, without requiring much versatility of their leaders, if compared to other projects studied in PM literature.

The results stood out the competence of innovation and adaptation, as well as taskoriented planning goals, as key competences of Six Sigma project leaders. In addition, for Six Sigma projects succeed, the leader should have the ability to perform in pressure situations and balance the strategic vision while dealing with the strict monitoring of the progress of the delegated tasks. Moreover, the selection of Black Belts should emphasize the natural capacity of the leadership.

A limitation of the study was the measurement of the behaviors competencies applying the $\mathrm{PI}^{\oplus}$ because it is a common used tool in Six Sigma program environment. This methodological choice caused a sample bias because some companies perform PI ${ }^{\circledR}$, for selecting Black Belts, which may have caused the low capacity of validation of the constructs in this study. Another limitation of the study is the sample size, which was not large enough to allow the validation of concepts within each demographic variables.

\section{References}

Ahsan, K., Ho, M., \& Khan, S. (2013).Recruiting project managers: A comparative analysis of competencies and recruitment signals from job advertisements. Project Management Journal, 44(5), 36-54.
Archibald, R. D. (2003). Managing high technology programs and projects. New Jersey: Wiley \& Sons.

Belout, A., \& Gauvreau, C. (2004). Factors influencing project success: The impact of human resource management. International Journal of Project Management, 22(1), 1-11.

Boyatzis, R. E. (1982). The competent manager: $A$ model for effective performance. New York: Wiley $\&$ Sons.

Bredin, K., \& Soderlund, J. (2013). Project managers and career models: An exploratory comparative study. International Journal of Project Management, 31(6), 889-902.

Brill, J., Bishop, M. J., \& Walker, A. (2006). The competencies and characteristics required of an effective project manager: A web-based delphi study. Educational Technology Research and Development, 54(2),115-140.

Buch, K. K., \& Tolentino, A. (2006).Employee expectations for Six Sigma success. Leadership \& Organization Development Journal, 27(1), 28-37.

Carvalho, M. M. (2014).An investigation of the role of communication in it projects. International Journal of Operations \& Production Management, 34(1), 36-64.

Carvalho, M. M., Ho, L. L., \& Pinto, S. H. B. (2007). Implementação e difusão do programa Seis Sigma no Brasil. Revista Produção, 17(3), 486-501.

Chang Dong, K. B., \& Zai, L. (2004).A study of critical success factors of information system project in China. Pmi Research Conference, p. 1-15.

Chipulu, M., Ojiako, U., \&Williams, T. (2013).A multidimensional analysis of project manager competences.IEEE Transactions on Engineering Management, 60(3), 506-517. 
Choo, A. S., Linderman, K. W., \&Schroeder, R. G. (2007).Method and psychological effects on learning behaviors and knowledge creation in quality improvement projects. Management Science, 53(3), 437-450.

Clarke, N. (2010). Emotional intelligence and its relationship to transformational leadership and key project manager competences. Project Management Journal, 41(2) 5-20.

Cooke-Davies, T. (2002). The "real" success factors on projects. International Journal of Project Management, 23(3), 185-190.

Crawford, L. (1998). Project management for strategy realization. Proceedings of World Congress on Project Management, Slovenia, 14. Recovered from https://www. researchgate.net/profile/Lynn_Crawford3/ publication/237648165_Project_Management_ Competence_for_the_New_Millenium/ links/0046352d06120c4460000000.pdf

Dainty, A. R. J., Chang, M., \& Moore, D. (2005). Competency-based model for predicting construction project managers' performance. Journal of Management, 21(1), 2-9.

Davison, L., \& Al-Shaghana, K. (2007).The link between six sigma and quality culture: An empirical study. Total Quality Management \& Business Excellence, 18(3), 249-265.

Everton, W. (1999). A further investigation of the construct validity of the predictive index ${ }^{\oplus}$. Wellesley Hills: Praendex.

Fabi, B., \& Pettersen, N. (1992).Human resource management practices in project management. International Journal of Project Management, 10(2), 281-288.

Faraj, S., \& Sambamurthy, V.(2006).Leadership of information systems development projects. IEEE
Transactions on Engineering Management,53(2), 238-249.

Galvani, L. R., \& Carpinetti, L. C. R. (2013). Análise comparativa da aplicação do programa Seis Sigma em processos de manufatura e serviços. Produção, 23(4), 695-704.

Gijo, E. V., \& Rao, T. S. (2005).Six Sigma implementation - Hurdles and more hurdles. Total Quality Management \& Business Excellence, 16(6),721-725.

Hair, J. F., Jr., Black, W. C., Babin, B. J., Anderson, R. E., \& Tatham, R. L. (2009). Análise multivariada de dados (6a ed.). Porto Alegre: Bookman.

Harry, M. J., Mann, P. S, Hodgins, O. C., Hulbert, R. L., \& Lacke, C. J. (2010). Practitioner's guide to statistics and lean six sigma for process improvement. New Jersey: Wiley \& Sons.

Harry, M., \& Schroeder, R. (2000). Six Sigma: The new breakthrough management strategy revolutionizing the world's top corporation. New York: Currency Doubleday.

International Project Management Association. (2006).Competence baseline version 3.O. Nijkerk: International Project Management Association.

Johnson, A., \& Swisher, B. (2003). How Six Sigma improves R\&D. Research-Technology Management, 46(2), 12-15.

Kaynack, H.(2003). The Relationship between total quality management practices and their effects on firm performance. Journal of Operations Management, 21(4),405-435.

Kerzner, H. R.(1998).In search of excellence in project management: Successful practices in high performance organizations. New York: Wiley \& Sons. 
Kessler, H., \& Winkelhofer, G.(2002). Projektmanagement: Leitfaden zur steuerung und führung von projekten. Heidenberg: Springer.

Kondic, Z., Maglic, L., \& Samerdzic, I.(2009). Analysis and ranking of factors impacting application of the 6 sigma: methodology in small production organizations using the prior factor ranking method. Technical Gazette, 16(2),17-25.

Kumar, M., \& Antony, J.(2008).Comparing the quality management practices in UK SMEs. Industrial Management \& Data Systems, 108(9), 1153-1166.

Kwak, Y. H., \& Anbari, F. T. (2006).Benefits, obstacles, and future of Six Sigma Approach. Technovation, 26(5-6),708-715.

Larson, E. W., \& Gobeli, D. H. (1989). Significance of project management structure on development success.IEEE Transactions on Engineering Management,36(2), 119-125.

Linderman, K., Schroeder, R. G., Zaheer, S., \& Choo, A. S. (2003).Six Sigma: A goaltheoretic perspective. Journal of Operations Management,21(2), 193-203.

Muller, R., \& Turner, J. R.(2010). Attitudes and leadership competences for project success. Baltic Journal of Management, 5(3),307-329.

Pande, P.S., Neuman, R. P., \& Cavanagh, R. R. (2001). Estratégia Seis Sigma. Rio de Janeiro: Qualitymark.

Perry, J. C., \& Lavori, P. W. (1983). The Predictive Index : A report on reliability and construct validity. Massachusetts: Praendex.

Picq, T.(2011).Manager une équipe projet. Paris: Dunod.

Pinto, J. K., \& Prescott, J. E. (1988). Variations in critical success factors over the stages in the project life cycle. Journal of Management, 14(1), 5-18.
Project Management Institute. (2007). The guide to project management body of knowledge: PMBOK. Pennsylvania: Project Management Institute.

Project Management Institute.(2013). The guide to project management body of knowledge: PMBOK. Pennsylvania: Project Management Institute.

Rabechini, R., Jr. \& Carvalho, M. M. (2003). Perfil das competências em equipes de projetos. RAE Eletrônica, (2)1, 1-17. Recovered from http://www.scielo.br/pdf/raeel/v2n1/v2n1a12

Rabechini, R., Jr. Carvalho, M. M., \&Laurindo, F. J. B. (2002). Fatores críticos para implementação de gerenciamento por projetos: $\mathrm{O}$ caso de uma organização de pesquisa. Produção, 23(2),28-41.

Rose, J., Pedersen, K., Hosbond, J. H., \& Kraemmergaard, P. (2007). Management competences, not tools and techniques: A grounded examination of software project management at Wm-data. Information and Software Technology, 49(6), 605-624.

Schroeder, R. G., Linderman, K., Liedtke, C., \& Choo, A. S. (2008).Six Sigma: Definition and underlying theory. Journal of Operations Management,26(4), 536-554.

Shao, J., \& Muller, R. (2011).The development of constructs of program context and program success: A qualitative study. International Journal of Project Management, 29(8),947-959.

Shenhar, A. J., \& Dvir, D. (2007). Reinventing project management: The diamond approach to successful growth and innovation. Boston: Harvard Business School Publishing.

Shtub, A., \& Globerson, S. (1994).Project management: Engineering, technology, and implementation. New Jersey: Prentice Hall. 
Skulmoski, G. J., \& Hartman, F. T. (2010). Information systems project manager soft competencies: A project-phase investigation. Project Management Journal, 41(1), 61-80.

Snee, R. D. (2001). Dealing with the achilles heel of six sigma initiatives. Quality Progress,34(3), 66.

Sommerville, J., \& Langford, J.(1994). Multivariate influences on the people side of projects: Stress and conflict. International Journal Of Project Management, 12(4),234-243.

Stevenson, D. H., \& Starkweather, J. A. (2010). PM critical competency index: It execs prefer soft skills. International Journal Of Project Management, 28(7),663-671.

Strang, K. D. (2007).Examining effective technology project leadership traits and behaviours. Computers in Human Behaviour, 23(1), 424-462.

The Standish Group.(2009). The 10 laws of chaos. Boston, MA

Thévenet, L.-H., Salinesi, C., Etien, A., Gam, I., \& Lassoued, M. (2006). Experimenting a modeling approach for designing organization's strategies, in the context of strategic alignment. Proceedings of the Australian Workshop on Requirements Engineering - AWRE, Adelaide, Australia, 11. Recovered from http://awre2006. cis.unisa.edu.au/proceedings/Paper\%203\%20 L.\%20Thevenet.pdf
Trad, S., \& Maximiniano, A. C. A. (2009). Seis Sigma: Fatores críticos de sucesso para sua implantação. Revista de Administração Contemporânea, 13(4), 647-662.

Tukel, O. I., \& Rom, W. O. (2001).An empirical investigation of project evaluation criteria. International Journal of Operations \& Production Management, 21(3), 400-416.

Van Iwaarden, J., Van der Wielea, T., Daleb, B, Williamsa, R.,\& Bertscha, B. (2008). The Six Sigma improvement approach: A transnational comparison. International Journal of Production Research, 46(23), 6739-6758.

White, D., \& Fortune, J. (2002). Current Practice in project management: An empirical study. International Journal of Project Management, 2O(1), 1-11.

Yeung, A. C. L., Cheng, T. C. E., \& Lai, K.H. (2006). An operational and institutional perspective on total quality management. Production and Operations Management, 15(1), 156-170.

Zu, X., Fredendall, L. D., \& Douglas, T. J. (2008). The evolving theory of quality management: The role of Six Sigma. Journal of Operations Management, 26(5), 630-650. 
Supporting agencies: The authors gratefully acknowledge the financial support of Brazil's National Council for Scientific and Technological Development (Conselho Nacional de Desenvolvimento Científico e Tecnológico, CNPq).

\section{About the authors:}

1. Daniela Santana Lambert Marzagáo, PhD in Production Engineering, University of São Paulo - USP, Brazil. Email: dslm0401@gmail.com

2. Marly M. Carvalho, PhD in Production Engineering,, University of São Paulo - USP, Brazil. Email: marlymc@usp.br

\section{Contribution of each author:}

\begin{tabular}{lcc}
\hline Contribution & Daniela S. L. Marzagáo & Marly M. Carvalho \\
\hline 1. Definition of research problem & $\sqrt{ }$ & $\sqrt{ }$ \\
2. Development of hypotheses or research questions (empirical studies) & $\sqrt{ }$ \\
3. Development of theoretical propositions (theoretical Work) & $\sqrt{ }$ & $\sqrt{ }$ \\
4. Theoretical foundation/ Literature review & $\sqrt{ }$ \\
5. Definition of methodological procedures & $\sqrt{ }$ & $\sqrt{ }$ \\
6. Data collection & $\sqrt{ }$ \\
7. Statistical analysis & $\sqrt{ }$ \\
8. Analysis and interpretation of data & $\sqrt{ }$ \\
9. Critical revision of the manuscript & $\sqrt{ }$ \\
10. Manuscript Writing & $\sqrt{ }$ & $\sqrt{ }$ \\
\hline
\end{tabular}

